http://dx.doi.org/10.5012/bkcs.2014.35.10.2922

\title{
Exploration of Isosteric Replacement of Imidazolidinone Motif in 4-Phenyl-1-arylsul- fonylimidazolidinone with Pyrazole and Pyrazolidinone for Cytotoxicity
}

\author{
Santhosh Subramanian, Vinay K. Sharma, Jieun Yun, ${ }^{\dagger}$ and Sang-Hun Jung ${ }^{*}$ \\ College of Pharmacy and Institute of Drug Research and Development, Chungnam National University, Daejeon 305-764, Korea \\ *E-mail:jungshh@cnu.ac.kr \\ ${ }^{\dagger}$ Bio-Evaluation Center, Korea Research Institute of Bioscience and Biotechnology, Chungcheongbuk-do 363-883, Korea \\ Received April 28, 2014, Accepted June 5, 2014
}

\begin{abstract}
To investigate the possible isosteric replacement of imidazolidinone moiety in 4-phenyl-1-arylsulfonylimidazolidinones (2) for broad and potent anti-cancer agents, a series of 5-phenyl-1 $H$-pyrazol-3-yl 1(acyl)indoline-5-sulfonates (4) and 1-(1-(acyl)indolin-5-ylsulfonyl)-5-phenylpyrazolidin-3-ones (5) were prepared and evaluated for their cytotoxicity against six human cancer cell lines. Although the pyrazoles $\mathbf{4}$ or pyrazolidinones $\mathbf{5}$ showed relatively good activity, still they showed lesser activity in comparison to imidazolidinones $\mathbf{2}$. These activity decreases could be interpreted with the effect of change of the hydrogen bonding characteristics and the substitution pattern on structural variations of five membered rings from imidazolidinones $\mathbf{2}$ to pyrazoles $\mathbf{4}$ and pyrazolidinones $\mathbf{5}$, respectively. Therefore, it can be concluded that $\mathbf{4 -}$ phenyl-1-arylsulfonylimidazolidinone is a basic pharmacophore of imidazolidinones $\mathbf{2}$.
\end{abstract}

Key Words : Arylsulfonylimidazolidinone, Pyrazolones, Pyrazolidinones, Cytotoxicity

\section{Introduction}

Although greater understanding and high quality of research resulted in higher cure rates for a number of malignancies, still the cancer remains one of the leading cause of death in the world. ${ }^{2,3}$ It is speculated that in next fifteen years there will be about twenty six million new cancer cases and seventeen million cancer deaths per year. ${ }^{1}$

Therefore we have investigated various derivatives of the 4-phenyl-1 $(N)$-arylsulfonylimidazolidinones $\mathbf{1}$ and $\mathbf{2}$ (Fig. 1) as potent anti-cancer agents. ${ }^{4-7}$ The SAR studies ${ }^{8-13}$ of these arylsulfonylimidazolidinones revealed 4-phenyl-1-benzenesulfonylimidazolidinone as the basic scaffold responsible for the potent anti-cancer activity. Though these arylsulfonylimidazolidinones showed potent activity, to produce the best anti-cancer agent we continually investigated various aspects of this scaffold which includes the replacement of phenyl ring at 4-position of imidazolidinone and the number of substituent at sulfonyl moiety. ${ }^{14-16}$ In addition to imidazolidinone ring, the role of $1 H$-imidazol-2(3H)-one (3) moiety (Fig. 1) in the basic pharmacophoric moiety has been studied. ${ }^{17}$ Interestingly, both scaffolds showed almost similar contribution to the activity against various cell lines. The mechanism of action of these arylsulfonylimidazolidinones has been established as tubulin polymerization inhibitors. ${ }^{18}$ These compounds retained the activity against multi drug resistant tumor cell lines, which implies that they are not a substrate for $p$-glycoprotein mediated transport like taxanes and vinca alkaloids derivatives. ${ }^{18}$ In continuation of our effort to get the potent anti-cancer agent new scaffold $4(1 \mathrm{H}$ pyrazol-3-ol) and 5 (pyrazolidinone) were designed by replacing imidazolidinone moiety in arylsulfonylimidazo-
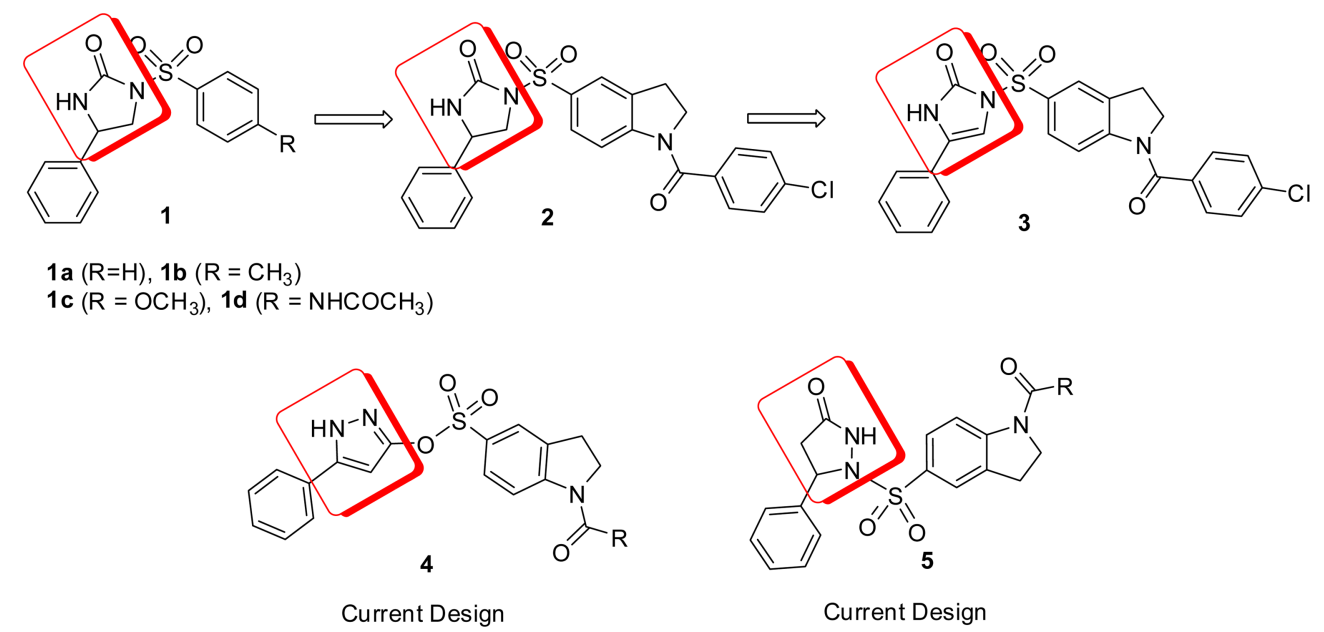

Figure 1. Structural modification of pyrazoles (4) and pyrazolidinones (5). 
lidinones 2 and studied them for their cytotoxicity. Thus, here in the current article, we have synthesized a number of 1H-pyrazol-3-ol analogs 4 and pyrazolidinones 5 (Fig. 1) for the evaluation of their cytotoxicity against six human cancer cell lines namely, prostate (PC-3), lung (NCI-H23), breast (MDA-MB-231), colon (HCT-15), stomach (NUGC-3) and renal (ACHN).

Chemistry. A series of analogs of pyrazolones 4 and pyrazolidin-3-ones $\mathbf{5}$ were prepared as illustrated in Scheme 1 and 2. The 5-phenyl-1H-pyrazol-3(2H)-one (7) was prepared by refluxing ethyl 3-oxo-3-phenylpropanoate (6) with hydrazine hydrate in ethanol for $8 \mathrm{~h} .{ }^{19}$

Compound 7 was then treated with 1-(2,2,2-trifluoroacetyl)indolin-5-ylsulfonyl chloride in presence of potassium carbonate in DMF to give a mixture of 5-phenyl- $1 H$-pyrazol3-yl 1-(2,2,2-trifluoroacetyl)indoline-5-sulfonate (8) and 5-
phenyl-1H-pyrazol-3-yl indoline-5-sulfonate (9). These sulfonates formation is attributed to the existence of stable lactim tautomer of 5-substituted- $1 H$-pyrazoles, ${ }^{19}$ which have the aromaticity. However, compound 9 was formed as major product as compared to compound $\mathbf{8}$, which can be converted to 9 by hydrolysis. Finally compound 9 was treated with various acyl chlorides and chloroformate in presence of pyridine to get compounds 4 (Scheme 1).

In next set of experiment for the preparation of pyrazolidinones 5, intermediate phenylpyrazolidin-3-ones (11) were prepared by refluxing the ethyl cinnamate (10) with hydrazine monohydrate in ethanol followed by heating with $2 \mathrm{~N}$ hydrochloric acid. ${ }^{20}$

Compound $\mathbf{1 1}$ was transformed to disulfonate $\mathbf{1 2}$ by the treatment with 1-(2,2,2 trifluoroacetyl)indoline-5-sulfonyl chloride in presence of triethylamine and DMF as shown in<smiles>[R]C(=O)N1CCc2cc(S(=O)(=O)Oc3cc(-c4ccccc4)[nH]n3)ccc21</smiles>

Scheme 1. Synthesis of pyrazoles $\mathbf{4 a - h}$.

Reagents and condition: i) $\mathrm{NH}_{2} \mathrm{NH}_{2} \cdot \mathrm{H}_{2} \mathrm{O}$, ethanol, reflux; ii) $\mathrm{K}_{2} \mathrm{CO}_{3}$, DMF, 1-(2,2,2-trifluoroacetyl)indoline-5-sulfonyl chloride, $0{ }^{\circ} \mathrm{C}$ to room temperature; iii) pyridine, methylene chloride, acyl chlorides or alkyl chloroformate, $0{ }^{\circ} \mathrm{C}$ to room temperature.

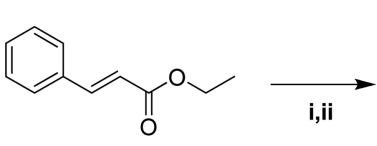

10<smiles>O=C1CNC(c2ccccc2)C1</smiles>

11<smiles>CC#CCC(C)(F)C(=O)N1CCc2cc(S(=O)(=O)N3C(=O)CC(c4ccccc4)N3S(=O)(=O)c3ccc4c(c3)CCN4C(=O)C(F)(F)F)ccc21</smiles>

12<smiles></smiles><smiles>O=C1CC(c2ccccc2)N(S(=O)(=O)c2ccc3c(c2)CCN3)C1</smiles>

14<smiles>[R]C(=O)N1CCc2cc(S(=O)(=O)N3NC(=O)CC3c3ccccc3)ccc21</smiles>

5

Scheme 2. Synthesis of $N$-arylsulfonylpyrazolidinones 5a-c.

Reagents and condition: (i) $\mathrm{NH}_{2} \mathrm{NH}_{2} \cdot \mathrm{H}_{2} \mathrm{O}$, ethanol, reflux; (ii) $2 \mathrm{~N}$ Hydrochloric acid, $60{ }^{\circ} \mathrm{C}$; (iii) Triethylamine, DMF, 1-(2,2,2trifluoroacetyl)indoline-5-sulfonyl chloride, $0{ }^{\circ} \mathrm{C}$ to RT; (iv) pyridine, methylene chloride, 1-(2,2,2-trifluoroacetyl)indoline-5-sulfonyl chloride; (v) lithium hydroxide monohydrate, tetrahydrofuran, water; (vi) pyridine, methylene chloride, acyl chloride. 
Table 1. Structures and Clog P values of 4a-h and 5a-c

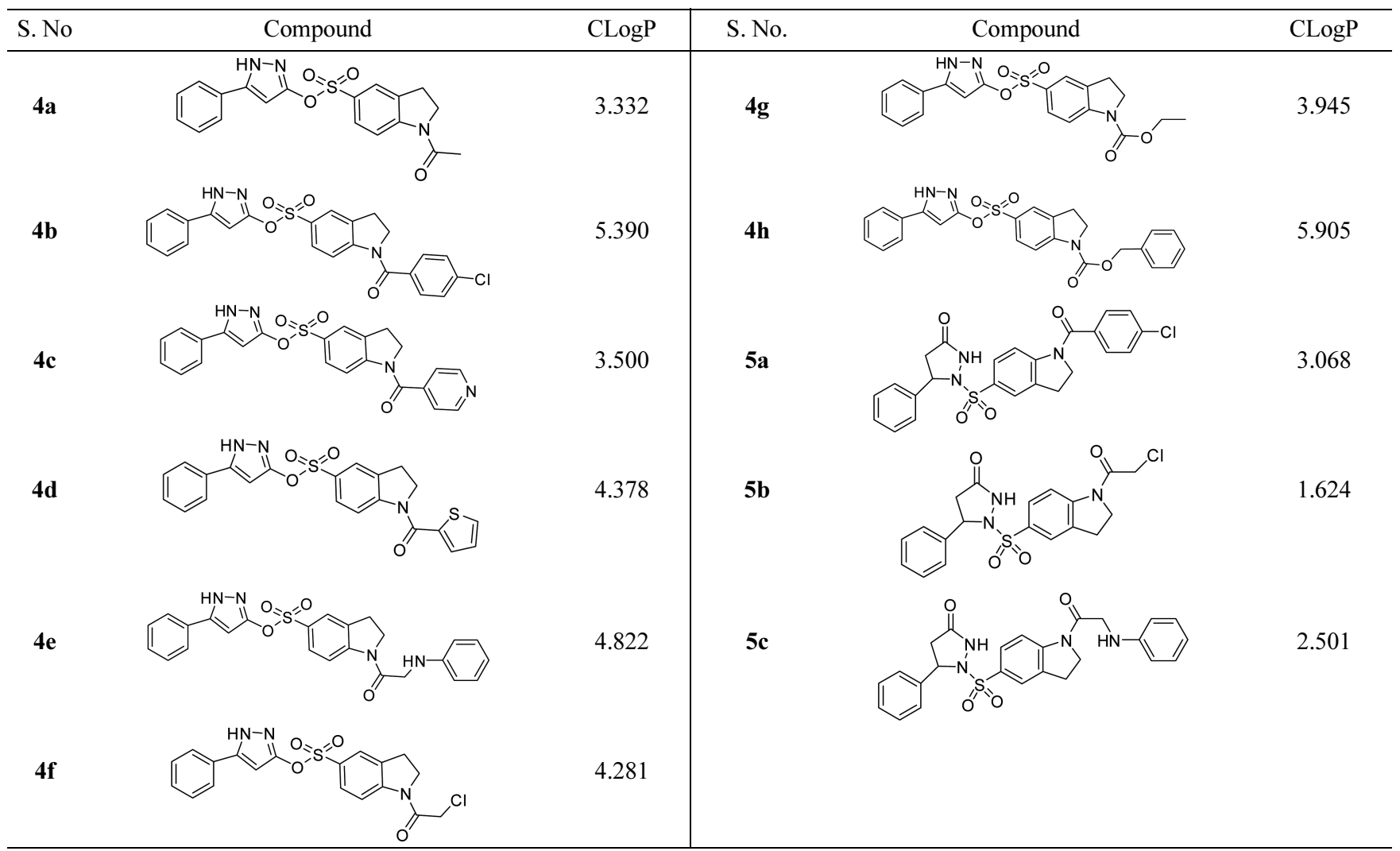

Scheme 2. However, variation of base and solvent to pyridine and methylene chloride for the same reaction of $\mathbf{1 1}$ produced sulfonamide 13. Hydrolysis of $\mathbf{1 3}$ to indoline $\mathbf{1 4}$ was accomplished by treatment with lithium hydroxide in presence of water and tetrahydrofuran. Later compound $\mathbf{1 4}$ was treated with various acyl chlorides in presence of pyridine to produce the final compound 5 (Scheme 2). All these synthesized compounds were characterized by physical and spectral analysis data that confirmed their assigned structures.

Biological Evaluation. The cytotoxicity of these new syn- thesized $\mathbf{4}$ and $\mathbf{5}$ was assessed against ACHN (renal), HCT15 (colon), MDA-MB-231 (breast), NCI-H23 (lung), NUGC3 (stomach) and PC-3 (prostate) cancer cell lines by the sulforhodamine B (SRB) colorimetric assay. ${ }^{21} \mathrm{GI}_{50}$ values are listed in parenthesis below along with this sequence of these cell lines written here. The concentrations required for $50 \%$ growth inhibition $\left(\mathrm{GI}_{50}\right)$ were listed in Table 2 .

\section{Result and Discussion}

In our previous studies we observed that the indoline

Table 2. In vitro anti-cancer activity of $N$-arylsulfonylpyrazoles (4a-h) and $N$-arylsulfonylpyrazolidinones (5a-c)

\begin{tabular}{ccccccc}
\hline \multirow{2}{*}{ Compound No } & \multicolumn{5}{c}{$\mathrm{IC}_{50}(\mu \mathrm{M})^{a}$} \\
\cline { 2 - 7 } & ACHN & HCT15 & MDA-MB-231 & NCI-H23 & NUGC-3 & PC-3 \\
\hline $\mathbf{4 a}$ & 3.24 & 2.80 & 2.33 & 4.40 & 5.12 & 3.22 \\
$\mathbf{4 b}$ & 5.67 & 6.23 & 7.44 & 6.67 & 5.64 & 4.43 \\
$\mathbf{4} \mathbf{c}$ & 2.69 & 3.45 & 1.89 & 2.65 & 5.45 & 6.98 \\
$\mathbf{4 d}$ & 4.06 & 5.34 & 6.45 & 5.78 & 4.22 & 7.80 \\
$\mathbf{4} \mathbf{4 d}$ & 4.56 & 5.65 & 6.34 & 4.56 & 5.55 & 4.12 \\
$\mathbf{4 f}$ & 1.74 & 0.86 & 0.80 & 0.10 & 1.03 & 1.11 \\
$\mathbf{4 g}$ & 1.32 & 2.67 & 2.44 & 1.58 & 3.21 & 1.14 \\
$\mathbf{4 h}$ & 8.56 & 9.32 & 7.23 & 6.15 & 5.12 & 7.38 \\
$\mathbf{5 a}$ & 9.44 & 7.32 & 8.44 & 7.12 & 9.76 & 8.98 \\
$\mathbf{5 b}$ & 2.56 & 3.44 & 2.67 & 1.07 & 2.01 & 3.45 \\
$\mathbf{5 c}$ & 6.78 & 7.45 & 8.78 & 6.67 & 5.52 & 6.46 \\
Adriyamycin & 0.256 & 0.432 & 0.598 & 0.494 & 0.384 & 0.506 \\
\hline
\end{tabular}

${ }^{a} \mathrm{IC}_{50}$ values are taken as a mean from 3 experiments. 
moiety at sulfonyl group of $\mathbf{2}$ and $\mathbf{3}$ is important for the anticancer activity. ${ }^{17,22}$ Therefore pyrazole analogs 4 replacing various substituents at position 1 of indoline moiety were prepared. The acetyl (4a, $\mathrm{GI}_{50}$ values; $3.24 ; 2.80 ; 2.33 ; 4.40$; 2.12 and $3.22 \mu \mathrm{M}$ respectively), 4-chlorobenzoyl (4b, $\mathrm{GI}_{50}$ values; $5.67 ; 6.23 ; 7.44 ; 6.67 ; 5.64$ and $4.43 \mu \mathrm{M}$ respectively), isonicotinyl $\left(\mathbf{4 c}, \mathrm{GI}_{50}\right.$ values; $2.69 ; 3.45 ; 1.89 ; 2.65$; 5.45 and $6.98 \mu \mathrm{M}$ respectively), thiophene-2-carbonyl (4d, $\mathrm{GI}_{50}$ values; $4.06 ; 5.34 ; 6.45 ; 5.78 ; 4.22$ and $7.80 \mu \mathrm{M}$ respectively), 2-(phenylamino)acetyl (4e, $\mathrm{GI}_{50}$ values; $4.56 ; 5.65$; $6.34 ; 4.56 ; 5.55$ and $4.12 \mu \mathrm{M}$ respectively), 2-chloroacetyl (4f, $\mathrm{GI}_{50}$ values; $1.74 ; 0.86 ; 0.80 ; 0.10 ; 1.03$ and $1.11 \mu \mathrm{M}$ respectively), ethyloxycarbonyl (4g, $\mathrm{GI}_{50}$ values; $1.32 ; 2.67$; $2.44 ; 1.58 ; 3.21$ and $1.14 \mu \mathrm{M}$ respectively), and benzyloxycarbonyl $\left(\mathbf{4 h}, \mathrm{GI}_{50}\right.$ values; $8.56 ; 9.32 ; 7.23 ; 6.15 ; 5.12$ and $7.38 \mu \mathrm{M}$ respectively) analogs showed moderate cytotoxicity against all the cancer cell lines. Among all these pyrazole analogs, compound $4 \mathrm{f}$ showed the most potent cytotoxicity against all cancer cell lines tested. Variation of acyl group at position 1 of indoline ring does not affect the activity of $\mathbf{4}$ so much. However, analogs $\mathbf{4 c}, \mathbf{4 d}, \mathbf{4 f}$ and $\mathbf{4 g}$ with smaller size of acyl moiety or heterocyclic moiety showed better activity than hydrophobic acyl analogs such as $\mathbf{4 b}, \mathbf{4 e}$ and $\mathbf{4 h}$. Although pyrazole moiety of $\mathbf{4}$ can be considered as an isostere of imidazolidinone moiety of arylsulfonylimidazolidinones $\mathbf{1}$ in terms of hydrogen bonding acceptor, pyrazole analogs 4 showed weaker activity compared to arylsulfonylimidazolidinones. The pyrazoles $\mathbf{4}$ have the same substitution pattern around pyrazole ring with phenyl group and sulfonyl functional groups as imidazolidinones 2 as shown in Figure 2. However the sulfonylurea function in imidazolidinones 2 was changed to diazenylmethyl sulfonate structural unit. Thus the binding pattern of 2 to the target was obviously altered. As a result, the activity of $\mathbf{4}$ was decreased compared to those of $\mathbf{2}$. This result implies the importance of sulfonylurea motif of imidazolidinones 2 .

In another set of experiment, the 1-[1-(acyl)indolin-5-ylsulfonyl]-5-phenylpyrazolidin-3-ones 5 were prepared with variation of acyl moiety at position 1 of indoline group. 4Chlorobenzoyl (5a, IC 50 values; 9.44; 7.32; 8.44; 7.12; 9.76 and $8.98 \mu \mathrm{M}$ respectively), 2-chloroacetyl $\left(\mathbf{5 b}, \mathrm{IC}_{50}\right.$ values; $2.56 ; 3.44 ; 2.67 ; 1.07 ; 2.01$ and $3.45 \mu \mathrm{M}$ respectively) and 2(phenylamino)acetyl $\left(\mathbf{5 c}, \mathrm{IC}_{50}\right.$ values; $6.78 ; 7.45 ; 8.78 ; 6.67$; 5.52 and $6.45 \mu \mathrm{M}$ respectively) analogs also showed moderate activity. 2-Chloroacetyl derivative $(\mathbf{5 b})$ showed better activity than analogs with more bulky substituents such as 4chlorobenzoyl (5a) and 2-(phenylamino)acetyl (5c). The pyrazolidinones $\mathbf{5}$ analogs also showed the reduced activity compared to imidazolidinones $\mathbf{2}$. Although pyrazolidinone scaffold has the similar hydrogen bonding charateristics to imidazolidinone, the substitution pattern around pyrazolidinone was dramatically changed as shown in Figure 2. This may resulted in the decrease in the activity. Thus this result confirms the importance of the substitution pattern in 4-phenyl-1-arylsulfonylimidazolidiones $\mathbf{2}$.

\section{Conclusion}

To investigate the possibility of isosteric replacement of imidazolidinone of 1-arylsulfonylimidazolidinone 2 with pyrazole and pyrazolidinone, a series of pyrazoles $4 \mathbf{a}-\mathbf{h}$ and pyrazolidinones 5a-c were synthesized and their cytotoxicity against ACHN (renal), HCT-15 (colon), MDA-MB-231 (breast), NCI-H23 (lung), NUGC-3 (stomach) and PC-3 (prostate) cell lines were evaluated. Among all the derivatives compounds $\mathbf{4 f}$ and $\mathbf{4 g}$ showed the best activity against all cancer cell lines. Though all the pyrazoles 4 or pyrazolidinones $\mathbf{5}$ showed relatively good activity, still they showed lesser activity in comparison to imidazolidinones (2). These activity decreases could be interpreted with the effect of change of the hydrogen bonding characteristics and the substitution pattern on structural variations of five membered rings from imidazolidinones $\mathbf{2}$ to pyrazoles $\mathbf{4}$ and pyrazolidinones $\mathbf{5}$, respectively. Therefore, on the basis of our previous $^{14-18}$ and current studies, it can be concluded that 4phenyl-1-arylsulfonylimidazolidinone is a basic pharmacophore of imidazolidinones 2 . In addition, the SAR studies of 4 and 5 indicated that the smaller size of acyl moiety or heterocyclic moiety at position 1 of indoline in pyrazoles 4 or pyrazolidinones $\mathbf{5}$ is more important for the activity than the large hydrophobic acyl analogs.

\section{Experimental Section}

Chemistry. Melting points $(\mathrm{mp})$ were determined on an Electrothermal 1A 9100 MK2 apparatus and are uncorrected. All commercial chemicals were used as obtained and all solvents were purified prior to use applying standard procedures. ${ }^{34}$ Thin layer chromatography was performed on $\mathrm{E}$ Merck silica gel GF-254 pre-coated plates and identification was performed under UV illumination and colorization with $10 \%$ phosphomolybdic acid spray followed by heating. Flash column chromatography was performed on E Merck silica gel (230-400 mesh). Infrared spectra were recorded on

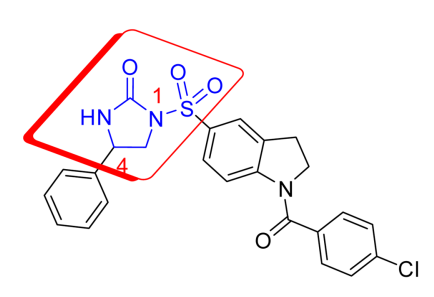

2

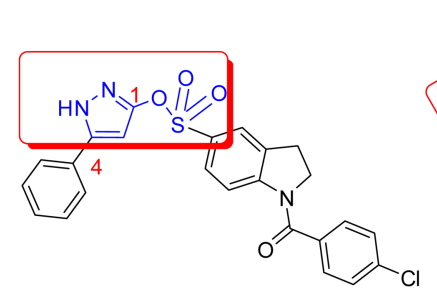

$4 b$

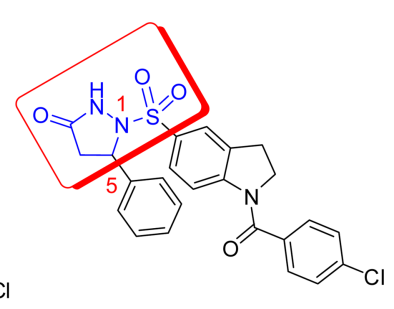

$5 a$

Figure 2. Structural comparison of imidazolidinone (2), pyrazole (4b) and pyrazolidinone (5a). 
a Nicolet 380 model FTIR. NMR spectra were measured against the peak of tetramethylsilane using a Varian Unity Inova $400 \mathrm{NMR}(400 \mathrm{MHz})$ spectrometer.

Synthesis of 5-Phenyl-1H-pyrazol-3(2H)-one (7). To the solution of ethyl benzoylacetate $(6,5 \mathrm{~g}, 26 \mathrm{mM})$ in $100 \mathrm{~mL}$ of ethanol, added hydrazine monohydrate $(5 \mathrm{~mL}, 60 \mathrm{mM})$ and the reaction mixture was refluxed for $8 \mathrm{~h}$. The reaction mixture was then cooled and filtered to get the white solid. The obtained solid was further recrystallized from ethanol twice to yield the desired compound 7 .

Yield 60\%; white solid; $R_{f} 0.23$ (hexane:ethyl acetate, 4:1); ${ }^{1} \mathrm{H} \mathrm{NMR}\left(\mathrm{CDCl}_{3}\right) \delta 5.89(\mathrm{~s}, 1 \mathrm{H}), 7.30(\mathrm{~m}, 1 \mathrm{H}) 7.66(\mathrm{~m}$, 2H), 7.66 (m, $2 \mathrm{H})$.

Synthesis of 5-Phenyl-1H-pyrazol-3-yl 1-(2,2,2-trifluoroacetyl)indoline-5-sulfonate (8) and 5-phenyl- $1 H$-pyrazol3-yl indoline-5-sulfonate (9). Added anhydrous potassium carbonate $(1.6 \mathrm{~g}, 12.5 \mathrm{mM})$ to a cold solution of 5-phenyl$1 H$-pyrazol-3(2H)-one $(7,1 \mathrm{~g}, 6.25 \mathrm{mM})$ and (1-(2,2,2-trifluoroacetyl)indolin-5-ylsulfonyl chloride $(2.0 \mathrm{~g}, 6.39 \mathrm{mM})$ in DMF and stirred the reaction mixture for $2 \mathrm{~h}$ at room temperature. After completion of the reaction was confirmed by TLC, the reaction mixture was mixed with ice cold water and extracted with ethyl acetate. Organic layer was dehydrated with anhydrous sodium sulfate and evaporated under reduced pressure. The crude solid was subjected to column chromatography to separate 8 and 9.

5-Phenyl-1H-pyrazol-3-yl 1-(2,2,2-trifluoroacetyl)indoline-5-sulfonate (8). Yield 10\%; white solid; $R_{f} 0.51$ (hexane: ethyl acetate, 2:3); $\mathrm{mp} 167{ }^{\circ} \mathrm{C}$; IR (neat) $3120,3015,2888$, 2355, 1937, 1698, $1595 \mathrm{~cm}^{-1} ;{ }^{1} \mathrm{H}$ NMR $\left(\mathrm{CDCl}_{3}\right) \delta 3.31(\mathrm{t}, J$ $=8.4 \mathrm{~Hz}, 2 \mathrm{H}), 4.36(\mathrm{t}, J=8.4 \mathrm{~Hz}, 2 \mathrm{H}), 6.38(\mathrm{~s}, 1 \mathrm{H}), 7.43-$ $7.49(\mathrm{~m}, 5 \mathrm{H}), 7.82(\mathrm{~m}, 2 \mathrm{H}), 8.29(\mathrm{~d}, J=8.0 \mathrm{~Hz}, 1 \mathrm{H})$.

5-Phenyl-1H-pyrazol-3-yl indoline-5-sulfonate (9). Yield $60 \%$; white solid; $R_{f} 0.24$ (hexane:ethyl acetate, $2: 3$ ); mp $162{ }^{\circ} \mathrm{C}$; IR (neat) 3334, 2958, 2916, 2613, 2358, 1890, 1607 $\mathrm{cm}^{-1} ;{ }^{1} \mathrm{H} \mathrm{NMR}\left(\mathrm{CDCl}_{3}\right) \delta 2.97(\mathrm{t}, J=8.4 \mathrm{~Hz}, 2 \mathrm{H}), 3.63(\mathrm{t}, J$ $=8.4 \mathrm{~Hz}, 2 \mathrm{H}), 6.35(\mathrm{~s}, 1 \mathrm{H}), 6.41(\mathrm{~d}, J=8.0 \mathrm{~Hz}, 1 \mathrm{H}), 7.43-$ $7.49(\mathrm{~m}, 5 \mathrm{H}) 7.53(\mathrm{~m}, 2 \mathrm{H})$.

General Procedure for Acylation of 5-phenyl-1H-pyrazol-3-yl indoline-5-sulfonate (4a-g). To the solution of 5phenyl-1H-pyrazol-3-yl indoline-5-sulfonate (9, 1 equivalent), pyridine (1.25 equivalent) in methylene chloride (10 $\mathrm{mL}$ ), appropriate acyl chloride (1.1 equivalent) was further added and the reaction mixture was stirred for $30 \mathrm{~min}$ at room temperature. After completion of reaction was confirmed on TLC, the reaction mixture was diluted with ethyl acetate and extracted with water. The organic layer was dried over sodium sulfate and evaporated under reduced pressure to afford a crude solid, which was further purified using column chromatography to yield the desired compound 4a-g.

Synthesis of 5-Phenyl-1 $\boldsymbol{H}$-pyrazol-3-yl 1-acetylindoline5-sulfonate (4a). Yield 55\%; White solid; $R_{f} 0.16$ (hexane: ethyl acetate, $2: 3$ ); $\mathrm{mp} 222{ }^{\circ} \mathrm{C}$; IR (neat) 3201, 3130, 2958, 2924, 2359, 1966, 1884, 1644, $1589 \mathrm{~cm}^{-1} ;{ }^{1} \mathrm{H} \mathrm{NMR}\left(\mathrm{CDCl}_{3}\right)$ $\delta 2.26(\mathrm{~s}, 3 \mathrm{H}), 3.25(\mathrm{t}, J=8.4 \mathrm{~Hz}, 2 \mathrm{H}), 4.14(\mathrm{t}, J=8.4 \mathrm{~Hz}$, $2 \mathrm{H}), 6.36(\mathrm{~s}, 1 \mathrm{H}), 7.30-7.58(\mathrm{~m}, 6 \mathrm{H}), 7.64-7.84(\mathrm{~m}, 2 \mathrm{H})$, $8.29(\mathrm{~d}, J=8.5 \mathrm{~Hz}, 1 \mathrm{H})$.

Synthesis of 5-Phenyl-1H-pyrazol-3-yl 1-(4-chlorobenzoyl)indoline-5-sulfonate (4b) Yield 47\%; white solid; $R_{f}$ 0.36 (hexane: ethyl acetate, $3: 2$ ); $\mathrm{mp} 224^{\circ} \mathrm{C}$; IR (neat) 3268 , 3036, 2924, 2654, 2359, 1967, 1809, 1638, 1585, $1565 \mathrm{~cm}^{-1}$; ${ }^{1} \mathrm{H} \mathrm{NMR}\left(\mathrm{CDCl}_{3}\right) \delta 3.18(\mathrm{t}, J=8.4 \mathrm{~Hz}, 2 \mathrm{H}) 4.12(\mathrm{t}, J=8.4$ $\mathrm{Hz}, 2 \mathrm{H}), 6.38$ (s, 1H), 7.37-7.54 (m, 9H), 7.73 (d, $J=7.8 \mathrm{~Hz}$, 1H), 7.79 (s, 1H), 9.96 (brs, 1H).

Synthesis of 5-Phenyl-1H-pyrazol-3-yl 1-isonicotinoylindoline-5-sulfonate (4c). Yield 52\%; white solid; $R_{f} 0.32$ (hexane:ethyl acetate, 1:4); mp $246{ }^{\circ} \mathrm{C}$; IR (neat) 3218, 3072, 2936, 1886, 1653, $1587 \mathrm{~cm}^{-1} ;{ }^{1} \mathrm{H}$ NMR $\left(\mathrm{CDCl}_{3}\right) \delta$ 3.23 (t, $J=8.4$ Hz, 2H), 4.09 (br. s., 2H), 6.40 (s, 1H), 7.357.56 (m, 8H), 7.65-7.89 (m, 2H), 8.80 (br. s., 2H), 9.81 (br. s., $1 \mathrm{H})$.

Synthesis of 5-Phenyl-1H-pyrazol-3-yl 1-(thiophene-2carbonyl)indoline-5-sulfonate (4d). Yield 48\%; white solid; $R_{f} 0.18$ (hexane:ethyl acetate, $2: 3$ ); mp $211^{\circ} \mathrm{C}$; IR (neat) $3338,3110,2930,2357,1910,1705,1632,1588 \mathrm{~cm}^{-1} ;{ }^{1} \mathrm{H}$ $\operatorname{NMR}\left(\mathrm{CDCl}_{3}\right) \delta 3.25(\mathrm{t}, J=8.4 \mathrm{~Hz}, 2 \mathrm{H}), 4.44(\mathrm{t}, J=8.4 \mathrm{~Hz}$, $2 \mathrm{H}), 6.37(\mathrm{~s}, 1 \mathrm{H}), 7.14(\mathrm{t}, J=4.4 \mathrm{~Hz}, 1 \mathrm{H}), 7.35-7.47(\mathrm{~m}$, $3 \mathrm{H})$, 7.47-7.53 (m, 2H), 7.58-7.65 (m, 2H), 7.71-7.78 (m, 2H), 8.18 (d, $J=8.3 \mathrm{~Hz}, 1 \mathrm{H}), 10.19$ (brs, $1 \mathrm{H})$.

Synthesis of Ethyl 5-(5-Phenyl-1H-pyrazol-3-yloxysulfonyl)indoline-1-carboxylate (4e). Yield 65\%; white solid; $R_{f} 0.16$ (hexane:ethyl acetate, $2: 3$ ); mp $196{ }^{\circ} \mathrm{C}$; IR (neat) 3284, 3133, 2990, 2358, 1695, 1594, $1566 \mathrm{~cm}^{-1} ;{ }^{1} \mathrm{H}$ $\operatorname{NMR}\left(\mathrm{CDCl}_{3}\right) \delta 1.36(\mathrm{t}, J=8.0 \mathrm{~Hz}, 3 \mathrm{H}), 3.15(\mathrm{t}, J=8.4 \mathrm{~Hz}$, $2 \mathrm{H}), 4.08$ (t, $J=8.4 \mathrm{~Hz}, 2 \mathrm{H}), 4.29$ (q, $J=8.0 \mathrm{~Hz}, 2 \mathrm{H}), 6.35$ (s, 1H), 7.43-7.49 (m, 6H), $7.73(\mathrm{~m}, 2 \mathrm{H}), 10.00(\mathrm{~d}, J=8.0$ $\mathrm{Hz}, 1 \mathrm{H})$.

Synthesis of 5-Phenyl-1H-pyrazol-3-yl 1-(2-chloroacetyl)indoline-5-sulfonate (4f). Yield 45\%; white solid; $R_{f} 0.12$ (hexane:ethyl acetate, 2:3); mp $192{ }^{\circ} \mathrm{C}$; IR (neat) 3384, 3190, 2993, 2942, 2597, 2359, 1979, 1683, $1595 \mathrm{~cm}^{-1} ;{ }^{1} \mathrm{H}$ $\mathrm{NMR}\left(\mathrm{CDCl}_{3}\right) \delta 3.29(\mathrm{t}, J=8.4 \mathrm{~Hz}, 2 \mathrm{H}), 4.17(\mathrm{~s}, 2 \mathrm{H}), 4.25$ $(\mathrm{t}, J=8.4 \mathrm{~Hz}, 2 \mathrm{H}), 6.37(\mathrm{~s}, 1 \mathrm{H}), 7.37-7.53(\mathrm{~m}, 5 \mathrm{H}), 7.72-$ $7.80(\mathrm{~m}, 2 \mathrm{H}), 8.29$ (d, $J=9.0 \mathrm{~Hz}, 1 \mathrm{H}), 9.97$ (brs, 1H).

Synthesis of Benzyl 5-(5-Phenyl-1H-pyrazol-3-yloxysulfonyl)indoline-1-carboxylate (4g). Yield 52\%; white solid; $R_{f} 0.18$ (hexane:ethyl acetate, $3: 2$ ); mp $105{ }^{\circ} \mathrm{C}$; IR (neat) 3630, 3144, 3030, 2359, 1710, 1598, 1560, 1488, $1437 \mathrm{~cm}^{-1} ;{ }^{1} \mathrm{H} \mathrm{NMR}\left(\mathrm{CDCl}_{3}\right) \delta 3.15(\mathrm{t}, J=8.4 \mathrm{~Hz}, 2 \mathrm{H}), 4.11$ $(\mathrm{t}, J=8.4 \mathrm{~Hz}, 2 \mathrm{H}), 5.27(\mathrm{~s}, 2 \mathrm{H}), 6.34(\mathrm{~s}, 1 \mathrm{H}), 7.29-7.52(\mathrm{~m}$, $11 \mathrm{H}), 7.59-7.82(\mathrm{~m}, 2 \mathrm{H}), 10.00$ (brs, $1 \mathrm{H})$.

Synthesis of 5-Phenyl-1H-pyrazol-3-yl 1-(2-(phenylamino)acetyl)indoline-5-sulfonate $(4 \mathrm{~h})$. To a solution of 5phenyl-1H-pyrazol-3-yl 1-(2-chloroacetyl)indoline-5-sulfonate $(\mathbf{4 f}, 0.1 \mathrm{~g}, 0.23 \mathrm{mM})$ in methylene chloride $(10 \mathrm{~mL})$, aniline $(0.05 \mathrm{~mL}, 0.5 \mathrm{mM})$ was added and the reaction mixture was stirred for $1 \mathrm{~h}$ at room temperature. The solvent was removed under reduced pressure and the crude mixture was subjected to column chromatography to get pure $\mathbf{4 h}$.

Yield 65\%, white solid; $R_{f} 0.19$ (hexane:ethylacetate, 2:3); mp $169{ }^{\circ} \mathrm{C}$; IR (neat) 3369, 3219, 2357, 1672, $1602 \mathrm{~cm}^{-1} ;{ }^{1} \mathrm{H}$ $\operatorname{NMR}\left(\mathrm{CDCl}_{3}\right) \delta 3.26(\mathrm{t}, J=8.4 \mathrm{~Hz}, 2 \mathrm{H}) 3.96(\mathrm{~s}, 2 \mathrm{H}) 4.11(\mathrm{t}$, $J=8.4 \mathrm{~Hz}, 2 \mathrm{H}) 6.37(\mathrm{~s}, 1 \mathrm{H}) 6.64(\mathrm{~d}, J=7.5 \mathrm{~Hz}, 2 \mathrm{H}) 6.76(\mathrm{t}$, 
$J=7.5 \mathrm{~Hz}, 1 \mathrm{H}) 7.21(\mathrm{dd}, J=8.4,7.4 \mathrm{~Hz}, 2 \mathrm{H}) 7.35-7.51(\mathrm{~m}$, 7H) $7.66-7.79(\mathrm{~m}, 2 \mathrm{H}) 8.28(\mathrm{~d}, J=9.0 \mathrm{~Hz}, 1 \mathrm{H})$.

Synthesis of 5-Phenylpyrazolidin-3-one (11). To the solution of ethyl cinnamate $(\mathbf{1 0}, 5 \mathrm{~g}, 28.4 \mathrm{mM})$ in $125 \mathrm{~mL}$ of ethanol, added hydrazine monohydrate $(5 \mathrm{~mL}, 60 \mathrm{mM})$ and refluxed for $10 \mathrm{~h}$. The solvent was then removed under reduced pressure to afford a viscous material. The viscous material was mixed with $20 \mathrm{~mL}$ of $2 \mathrm{~N}$ hydrochloric acid and the mixture was heated to $50{ }^{\circ} \mathrm{C}$ for $5 \mathrm{~h}$. The resultant solution was cooled and neutralized with saturated sodium bicarbonate solution and extracted with ethyl acetate. The organic layer was washed with brine and evaporated the solvent under reduced pressure to obtain the residue. The residue obtained was further recrystallized with mixture of acetone:toluene (1:9) to afford the compound 11.

Yield $65 \%$; $R_{f} 0.15$ (hexane:ethylacetate, 4:6); ${ }^{1} \mathrm{H}$ NMR $\left(\mathrm{DMSO}-d_{6}\right) \delta 2.35(\mathrm{dd}, J=15.6,7.5 \mathrm{~Hz}, 1 \mathrm{H}), 2.72(\mathrm{dd}, J=$ 15.6, 7.5 Hz, 1H), 4.59 (d, $J=7.5 \mathrm{~Hz}, 1 \mathrm{H}), 5.59$ (d, $J=8.0$ $\mathrm{Hz}, 1 \mathrm{H}), 7.11-7.54$ (m, 5H), 9.19 (s, 1H).

Synthesis of 5-Phenyl-1,2-bis[(1-(2,2,2-trifluoroacetyl)indolin-5-ylsulfonyl)]pyrazolidin-3-one (12). To a cold solution of 5-phenylpyrazolidin-3-one (11, $0.5 \mathrm{~g}, 3.08 \mathrm{mM})$ in $5 \mathrm{~mL}$ of DMF, triethylamine $(0.7 \mathrm{~mL}, 4.9 \mathrm{mM})$ and (1(2,2,2-trifluoroacetyl)indolin-5-ylsulfonyl chloride (1.2 g, $3.85 \mathrm{mM}$ ) were added and the reaction mixture was stirred for $4 \mathrm{~h}$ at room temperature. After completion of the reaction was confirmed by TLC, the reaction mixture was extracted with ethyl acetate and water. The organic layer was washed with brine and dried over anhydrous sodium sulfate and evaporated under reduced pressure to yield a crude solid, which was subjected to column chromatography to yield the desired compound 12.

Yield 75\%; ${ }^{1} \mathrm{H}$ NMR $\left(\mathrm{CDCl}_{3}\right) \delta 2.91(\mathrm{dd}, J=17.8,9.6 \mathrm{~Hz}$, $1 \mathrm{H}), 3.18(\mathrm{dd}, J=17.8,11.3 \mathrm{~Hz}, 1 \mathrm{H}), 3.57-3.28(\mathrm{~m}, 4 \mathrm{H})$, $4.43(\mathrm{~m}, 4 \mathrm{H}), 4.83(\mathrm{t}, J=10.4 \mathrm{~Hz}, 1 \mathrm{H}), 7.44-7.28(\mathrm{~m}, 5 \mathrm{H})$, 7.74-7.65 (m, 2H), $7.99(\mathrm{~d}, J=8.7 \mathrm{~Hz}, 1 \mathrm{H}), 8.03(\mathrm{~s}, 1 \mathrm{H})$, $8.30(\mathrm{~d}, J=8.5 \mathrm{~Hz}, 1 \mathrm{H}), 8.41(\mathrm{~d}, J=8.7 \mathrm{~Hz}, 1 \mathrm{H})$.

Synthesis of 5-Phenyl-1-(1-(2,2,2-trifluoroacetyl)indolin-5-ylsulfonyl)pyrazolidin-3-one (13). To a cold solution of 5-phenylpyrazolidin-3-one (11, $2 \mathrm{~g}, 12.3 \mathrm{mM})$ in $40 \mathrm{~mL}$ of methylene chloride added pyridine $(2 \mathrm{~mL}, 25.3 \mathrm{mM})$ and (1-(2,2,2-trifluoroacetyl)indolin-5-ylsulfonyl chloride (4 g, $12.7 \mathrm{mM})$. The reaction mixture was stirred for $4 \mathrm{~h}$ at room temperature. After completion of the reaction was confirmed by TLC, the reaction mixture was extracted with ethyl acetate and water. The organic layer was washed with brine and dried over anhydrous sodium sulfate and evaporated under reduced pressure to yield a crude solid. The solid was subjected to column chromatography to yield the desired compound 13.

Yield 73\%; white solid; $R_{f} 0.16$ (hexane: ethylacetate, 3:2); mp $199{ }^{\circ} \mathrm{C}$; IR (neat) 3144, 3080.7, 2358, 1713, 1597 $\mathrm{cm}^{-1} ;{ }^{1} \mathrm{H}$ NMR (DMSO- $\left.d_{6}\right) \delta$ 1.86-2.04 $(\mathrm{m}, 1 \mathrm{H}), 2.09(\mathrm{~m}$, $1 \mathrm{H}), 3.36(\mathrm{~m}, 2 \mathrm{H}), 4.41(\mathrm{~m}, 2 \mathrm{H}), 5.34-5.56(\mathrm{~m}, 1 \mathrm{H}), 7.14-$ $7.50(\mathrm{~m}, 5 \mathrm{H}), 7.82-8.06(\mathrm{~m}, 2 \mathrm{H}), 8.31(\mathrm{dd}, J=8.1,6.2 \mathrm{~Hz}$, $1 \mathrm{H}), 11.08$ (d, $J=5.3 \mathrm{~Hz}, 1 \mathrm{H})$.

Synthesis of 1-(Indolin-5-ylsulfonyl)-5-phenylpyrazo- lidin-3-one (14). To a cold solution 5-phenyl-1-(1-(2,2,2trifluoroacetyl)indolin-5-ylsulfonyl) pyrazolidin-3-one (13, $1 \mathrm{~g}, 2.27 \mathrm{mM})$ in $30 \mathrm{~mL}$ of tetrahydrofuran, lithium hydroxide monohydrate $(0.1 \mathrm{~g}, 2.4 \mathrm{mM})$ and water $(2 \mathrm{~mL})$ were added. The reaction mixture was stirred for $45 \mathrm{~min}$ at room temperature. After completion of the reaction was confirmed by TLC, the reaction was quenched with ammonium chloride $(0.25 \mathrm{~g}, 4.46 \mathrm{mM})$. The reaction mixture was diluted with ethyl acetate and extracted with brine and water. The organic layer was dried over sodium sulfate and evaporated under reduced pressure to afford the compound 14, which was purified by column chromatography.

Yield 67\%; white solid; mp $148{ }^{\circ} \mathrm{C}$; IR (neat) 3322, 3029, 2225, 1705, $1597 \mathrm{~cm}^{-1} ;{ }^{1} \mathrm{H}$ NMR (DMSO-d $\left.d_{6}\right) \delta 1.91-2.06$ $(\mathrm{m}, 2 \mathrm{H}), 3.06(\mathrm{t}, J=8.4 \mathrm{~Hz}, 2 \mathrm{H}), 3.62(\mathrm{t}, J=8.4 \mathrm{~Hz}, 2 \mathrm{H})$, 5.34-5.56 (m, 1H), 7.14-7.50 (m, 5H), 7.82-8.06 (m, 2H), 8.31 (dd, $J=8.2,6.2 \mathrm{~Hz}, 1 \mathrm{H}), 11.08$ (d, $J=5.3 \mathrm{~Hz}, 1 \mathrm{H})$.

General Procedure for Synthesis of Compound 5a-c. To the solution of 1-(indolin-5-ylsulfonyl)-5-phenylpyrazolidin-3-one (14, 1 equivalent) in methylene chloride (10 $\mathrm{mL}$ ), pyridine (1.25 equivalent) and acyl chloride (1.1 equivalent) were added and the reaction mixture was stirred for $30 \mathrm{~min}$ at room temperature. After completion of reaction was confirmed by TLC, the reaction mixture was diluted with ethyl acetate and washed with water. The organic layer was dried over anhydrous sodium sulfate and evaporated under reduced pressure to afford a crude solid, which was further purified using column chromatography to yield the desired compound (5a-c).

Synthesis of 1-(1-(4-chlorobenzoyl)indolin-5-ylsulfonyl)-5-phenylpyrazolidin-3-one (5a). Yield 48\%; white solid; $R_{f} 0.18$ (hexane:ethyl acetate, $3: 2$ ); $\mathrm{mp} 159{ }^{\circ} \mathrm{C}$; IR (neat) 3081, 3029, 2831, 2358, 1718, 1629, $1586 \mathrm{~cm}^{-1}$; ${ }^{1} \mathrm{H}$ NMR $\left(\mathrm{DMSO}-d_{6}\right) \delta 1.98(\mathrm{~d}, J=9.2 \mathrm{~Hz}, 1 \mathrm{H}), 2.04-2.25(\mathrm{~m}, 1 \mathrm{H})$, 3.23 (t, $J=8.4 \mathrm{~Hz}, 2 \mathrm{H}), 4.10$ (t, $J=8.4 \mathrm{~Hz}, 2 \mathrm{H}), 5.45$ (d, $J=$ 8.7 Hz, 1H), 7.19-7.47 (m, 6H), 7.54-7.65 (m, 2H), 7.70 (d, $J$ $=8.5 \mathrm{~Hz}, 2 \mathrm{H}), 7.81-7.97(\mathrm{~m}, 2 \mathrm{H}), 8.14(\mathrm{brs}, 1 \mathrm{H}), 11.04(\mathrm{~s}$, $1 \mathrm{H})$.

Synthesis of 5-Phenyl-1-(1-(2-chloroacetyl)indolin-5ylsulfonyl)pyrazolidin-3-one (5b). Yield 40\%; white solid; $R_{f} 0.18$ (hexane:ethyl acetate, $3: 2$ ); mp $189{ }^{\circ} \mathrm{C}$; IR (neat) 3081, 3029, 2831, 2358, 1718, 1629, $1586 \mathrm{~cm}^{-1}$; ${ }^{1} \mathrm{H}$ NMR $\left(\mathrm{CDCl}_{3}\right) \delta 1.98(\mathrm{~d}, J=9.2 \mathrm{~Hz}, 1 \mathrm{H}), 2.04-2.25(\mathrm{~m}, 1 \mathrm{H}), 3.29$ $(\mathrm{t}, J=8.4 \mathrm{~Hz}, 2 \mathrm{H}), 4.17(\mathrm{~s}, 2 \mathrm{H}), 4.25(\mathrm{t}, J=8.4 \mathrm{~Hz}, 2 \mathrm{H})$, $5.45(\mathrm{~d}, J=8.7 \mathrm{~Hz}, 1 \mathrm{H}), 7.37-7.53(\mathrm{~m}, 5 \mathrm{H}), 7.72-7.80(\mathrm{~m}$, $2 \mathrm{H}), 8.29(\mathrm{~d}, J=9.0 \mathrm{~Hz}, 1 \mathrm{H})$.

Synthesis of 5-Phenyl-1-(1-(2-(phenylamino)acetyl)indolin-5-ylsulfonyl)pyrazolidin-3-one (5c). To a solution of 1-(1-(2-chloroacetyl)indolin-5-ylsulfonyl)-5-phenylpyrazolidin-3-one $(\mathbf{5 b}, 0.1 \mathrm{~g}, 0.23 \mathrm{mM})$ in methylene chloride, aniline $(0.05 \mathrm{~mL}, 0.5 \mathrm{mM})$ was added and the reaction mixture was stirred at room temperature for $1 \mathrm{~h}$. After evaporation of the reaction mixture, the resulted mixture was further purified using column chromatography to obtain the compound $\mathbf{5 c}$.

Yield 55\%; White solid; $R_{f} 0.4$ (hexane:ethyl acetate, 2:3); $\operatorname{mp} 212{ }^{\circ} \mathrm{C}$; IR (neat) 3382, 3100, 2825, 2358, 1715, 1683, 
$1600 \mathrm{~cm}^{-1} ;{ }^{1} \mathrm{H}$ NMR (DMSO- $\left.d_{6}\right) \delta$ 1.67-1.97 (m, 1H), 2.00$2.17(\mathrm{~m}, 1 \mathrm{H}), 3.06-3.46(\mathrm{~m}, 2 \mathrm{H}), 4.33(\mathrm{t}, J=8.4 \mathrm{~Hz}, 2 \mathrm{H})$, $5.42(\mathrm{~d}, J=9.0 \mathrm{~Hz}, 1 \mathrm{H}), 6.36-6.84(\mathrm{~m}, 3 \mathrm{H}), 7.10(\mathrm{t}, J=6.9$ $\mathrm{Hz}, 2 \mathrm{H}), 7.27-7.56(\mathrm{~m}, 5 \mathrm{H}), 7.70-7.99$ (m, 2H), 8.29 (d, $J=$ $8.0 \mathrm{~Hz}, 1 \mathrm{H}), 11.02(\mathrm{~s}, 1 \mathrm{H})$.

Acknowledgments. This work was supported by Research Fund of Chungnam National University.

\section{References}

1. IARC. World Cancer Report, 2008. Boyle, P., Levin, B. E., Eds.; IARC Press: Lyon, 2008.

2. Eckhardt, S. Curr. Med. Chem.-Anti-Cancer Agents 2002, 2, 419.

3. Lee, C. W.; Hong, D. H.; Han, S. B.; Jong, S.-H.; Kim, H. C.; Fine, R. L.; Lee, S.-H.; Kim, H. M. Biochem. Pharmacol. 2002, 64, 473-480.

4. Lee, H.-S.; Park, K.-L.; Choi, S.-U.; Lee, C.-O.; Jung, S.-H. Arch. Pharm. Res. 2000, 23, 579.

5. Jung, S.-H.; Song, J.-S.; Lee, H.-S.; Choi, S.-U.; Lee, C.-O. Arch. Pharm. Res. 1996, 19, 570.

6. Jung, S.-H.; Song, J.-S.; Lee, H.-S.; Choi, S.-U.; Lee, C.-O. Bioorg. Med. Chem. Lett. 1996, 6, 2553.

7. Jung, S.-H.; Kwak, S.-J. Arch. Pharm. Res. 1997, 20, 283.

8. Jung, S.-H.; Lee, H-S.; Song, J.-S.; Kim, H.-M.; Han, S.-B.; Lee, C.-W.; Lee, M.; Choi, D.-R.; Lee, J.-A.; Chung, Y.-H.; Yoon, S.J.; Moon, E.-Y.; Hwang, H.-S.; Seong, S.-K.; Lee, D.-K. Bioorg. Med. Chem. Lett. 1998, 8, 1547.
9. Lee, H.-S.; Park, K.-L.; Choi, S.-U.; Lee, C.-O.; Jung, S.-H. Arch. Pharm. Res. 2000, 23, 579.

10. Jung, S.-H.; Park, K.-L.; Lee, H.-S.; Whang, J.-S. Arch. Pharm. Res. 2001, 24, 499.

11. Kim, I.-W.; Jung, S.-H. Arch. Pharm. Res. 2002, 25, 421.

12. Choo Park, H.-Y.; Choi, S.; Jung, S.-H.; Koh, H.-Y.; Pae, A.-N. Bioorg. Med. Chem. 2003, 11, 4585.

13. Kim, I.-W.; Lee, C.-K.; Kim, H.-S.; Jung, S.-H. Arch. Pharm. Res. 2003, 26, 9 .

14. Jung, S.-H.; Kwak, S.-J. Arch. Pharm. Res. 1997, 20, 283.

15. Jung, S.-H.; Kwak, S.-J.; Kim, N. D.; Lee, S.-U.; Lee, C.-O. Arch. Pharm Res. 2000, 23, 35.

16. Kwak, S.-H.; Bang, S.-C.; Seo, H.-H.; Shin, H.-R.; Lee, K.-C.; Hoang, L. T. A.; Jung, S.-H. Arch. Pharm Res. 2006, 29, 721.

17. Yoon, S. J.; Chung, Y. H.; Lee, M. S.; Choi, D. R.; Lee, J. A.; Lee, H. S.; Yun, H. R.; Lee, D. K.; Moon, E. Y.; Hwang, H. S.; Choi, C. H.; Jung, S.-H. 1999, U.S patent 592910327.

18. Kim, S.; Park, J.-H.; Koo, S.-Y.; Kim, J.-I ; Kim, M.-H.; Kim, E.J.; Jo, K.; Choi, H.-G.; Lee, S.-B.; Jung, S.-H. Bioorg. Med. Chem. Lett. 2004, 14, 6075.

19. Khalil, A. K.; Hassan, M. A.; Mohamed, M. M.; El-Sayed, A. M. Indian J. Chem. 2006, 45, 2485.

20. Aokoi, M., Patent. NO. JP 2001316371 FUJI PHOTO FILM CO LTD.

21. Skehan, P.; Storeng, R.; Scudiero, D.; Monks, A.; McMahon, J.; Vistica, D.; Warren, J. T.; Bokesch, H.; Kenney, S.; Boyd, M. R. J. Natl. Cancer Inst. 1990, 82, 1107.

22. Jung, S.-H.; Lee, H.-S.; Kim, N.-S.; Kim, H.-M.; Lee, M.; Choi, D.-R.; Lee, J.-A.; Chung, Y.-H.; Moon, E.-Y.; Hwang, H.-S.; Seong, S.-K.; Lee, D.-K. Arch. Pharm. Res. 2004, 27, 478. 